\title{
IS THERE GENETIC VARIABILITY IN DWARF COCONUT ACCESSIONS PRESERVED IN BRAZIL ${ }^{1}$
}

\author{
KAMILA MARCELINO BRITO SOBRAL ${ }^{2}$, MANOEL ABILIO DE QUEIROZ ${ }^{3}$, IZAIAS DA SILVA LIMA NETO ${ }^{4}$, \\ RONALDO SIMÃO DE OLIVEIRA ${ }^{5}$, SEMÍRAMIS RABELO RAMALHO RAMOS ${ }^{6} *$
}

\begin{abstract}
Dwarf coconut tree is the main variety for commercial use in Brazil, which ranks fourth in world coconut production. However, the genotypes used still have limitations and genetic variability is required. The aim of this study was to estimate the genetic variability in dwarf coconut accessions preserved at the Germplasm Bank of Brazil at different harvesting times and using agronomic descriptors of plant and fruits. The accessions Brazilian Green Dwarf-Jiqui, Cameroon Red Dwarf, Malayan Red Dwarf, Brazilian Red Dwarf -Gramame, Brazilian Yellow Dwarf-Gramame, and Malayan Yellow Dwarf were assessed by means of 30 descriptors Variance analysis was performed and the genetic diversity was quantified by using the Mahalanobis' generalized distance and expressed by means of UPGMA clusters, Tocher optimization, and canonical variables. The maximum likelihood analysis was used to estimate the components of variance with the data of each plant in a sample of 11 descriptors of great importance for the genetic improvement of the coconut tree. A phenotypic divergence was found among the accessions using the UPGMA clusters, Tocher optimization and graphic dispersion obtained with canonical variables. The use of the maximum likelihood analysis confirms the existence of genetic variability in the accessions for the descriptors fruit polar and equatorial diameter, nut polar diameter, total fruit weight, and epicarp thickness, which presented a heritability varying from 0.17 to 0.39 . There is a possibility of genetic gains with the selection of these traits for use of accessions in breeding programs.
\end{abstract}

Keywords: Cocos nucifera L. Phenotypic traits. Multivariate analysis. Germplasm. Plant genetic resources.

\section{HÁ VARIABILIDE GENÉTICA EM ACESSOS DE COQUEIRO-ANÃO CONSERVADOS NO BRASIL?}

RESUMO - O coqueiro anão é a principal variedade para uso comercial no Brasil, que ocupa atualmente a quarta posição na produção mundial. No entanto, os genótipos utilizados no país ainda apresentam limitações e há necessidade de variabilidade genética. Este trabalho teve por objetivo estimar a variabilidade genética em acessos de coqueiro-anão conservados no Banco de Germoplasma existente no Brasil, em diferentes épocas de colheita, utilizando descritores agronômicos de planta e frutos. Os acessos anão-verde-do-Brasil-de-Jiqui; anãovermelho-de-Camarões; anão-vermelho-da-Malásia; anão-vermelho-de-Gramame; anão-amarelo-de-Gramame e anão-amarelo-da-Malásia foram avaliados por meio de 30 descritores. Análise de variância foi realizada e a diversidade genética foi quantificada utilizando a distância generalizada de Mahalanobis e expressa por meio de agrupamentos UPGMA, otimização de Tocher e variáveis canônicas. A análise de máxima verossimilhança foi utilizada para estimar os componentes de variância com os dados de cada planta em uma amostra de 11 descritores de maior importância para o melhoramento genético do coqueiro. Foi encontrada divergência fenotípica entre os acessos usando os agrupamentos UPGMA, Tocher e a dispersão gráfica obtida com variáveis canônicas. $\mathrm{O}$ emprego da análise de máxima verossimilhança confirma a existência de variabilidade genética nos acessos para os descritores diâmetro polar e equatorial do fruto, diâmetro polar da noz, peso total do fruto e espessura de epicarpo que apresentaram herdabilidade variando de 0,17 a 0,39 . Há possibilidade de ganhos genéticos com a seleção desses caracteres para uso dos acessos em programas de melhoramento genético.

Palavras-chave: Cocos nucifera L. Características fenotípicas. Análise multivariada. Germoplasma. Recursos genéticos vegetais.

\footnotetext{
${ }^{*}$ Corresponding author

${ }^{1}$ Received for publication in $02 / 17 / 2017$; accepted in 09/06/2018.

Paper extracted from the doctoral thesis of the first author.

${ }^{2}$ Department of Biological Sciences, Universidade Estadual de Feira de Santana, Feira de Santana, BA, Brazil; milambrito@hotmail.com ORCID: 0000-0002-2005-6445.

${ }^{3}$ Department of Technology and Social Sciences, Universidade do Estado da Bahia, Juazeiro, BA, Brazil; manoelabiliomaq@gmail.com ORCID: 0000-0001-9501-2343.

${ }^{4}$ Center for Agrarian Sciences Universidade Federal do Vale do São Francisco, Petrolina, PE, Brazil; izaias.limaneto@univasf.edu.br ORCID: 0000-0002-7557-1102.

${ }^{5}$ Instituto Federal de Educação, Ciência e Tecnologia Baiano, Xique-Xique-BA, Brasil; ronaldosimaorso@gmail.com - ORCID: 0000-00030996-9144.

${ }^{6}$ Embrapa Tabuleiros Costeiros, Aracaju, SE, Brazil; semiramis.ramos@embrapa.br - ORCID: 0000-0003-1289-1341.
} 


\section{INTRODUCTION}

The coconut tree is a monospecific palm composed of three botanical varieties: Cocos nucifera L. var. typica (tall coconut), C. nucifera L. var. nana (dwarf coconut), and $C$. nucifera $\mathrm{L}$. var. aurantiaca (intermediate coconut) (LIYANAGE, 1958). The dwarf variety is small in size, reaching up to $12 \mathrm{~m}$ when fully grown, an early cycle when compared to the tall coconut, and depending on the environment, it can start flowering around two years and six months after planting, producing a high number of small fruits (150 to 200 fruits/plant/year) (MENON; PADALAI, 1958; ARAGÃO et al., 2002). This variety is composed of yellow, green, and red cultivars (OHLER, 1984). In Asian, African, and some Latin American countries, dwarf coconuts are usually used for ornamental purposes and in breeding programs, especially in the intervarietal hybridization process with tall coconut (ARAGÃO et al., 2002).

Indonesia is the world's largest producer $(17,722,429$ tons), followed by the Philippines $(13,825,080$ tons), and India (11,127,898 tons) (FAOSTAT, 2016). Brazil occupies the fourth position, with a production of over 2,649,246 tons in a planted area of 234,012 ha (FAOSTAT, 2016), and the green dwarf is the cultivar mainly used for commercial production.

In recent years, an increase of areas used for cultivation and production has been seen in different parts of the world. In Brazil, the advance of the crop occurs not only by the evolution in production levels, giving it a prominent place among the world's largest coconut producers, but also by the expansion into regions not traditionally used for cultivation. Coconut cultivation in Brazil traditionally occurs in the Northeast region, but in the last 30 years, the cultivation areas have spread into other regions of Brazil, mainly in the Southeast, Midwest, and North (MARTINS; JESUS JUNIOR, 2014).

In Brazil, dwarf coconut accessions are preserved in the International Coconut Genebank for Latin America and the Caribbean (ICG-LAC), unique in the country and located at Embrapa Coastal Tablelands, in Aracaju, SE. Since their implantation, the accessions have been assessed and characterized and most of the studies were carried out using an official descriptive list for the species (IPGRI, 1995). However, some assessments were carried out in a preliminary scope and with data only measured from a single production cycle. In order to assess the preserved accessions in depth and to access as much information as possible, it is necessary to carry out studies of different production cycles, in sequential years, in which the maximum number of descriptors can be used. The results obtained from these studies will provide information about the genetic variability, which is essential for future decision-making, both for accession conservation and for breeding programs. In this sense, the dwarf coconut is an autogamous variety and its germplasm has a high degree of homozygosity. Thus, knowledge about the variability among the accessions preserved in the germplasm bank will also allow the identification of parental potentials and exploration of the heterosis. The aim of this study was to estimate the genetic variability in accessions of dwarf coconut preserved in the ICGLAC at different harvest times and using agronomic fruit and plant descriptors.

\section{MATERIAL AND METHODS}

Six 15-year-old dwarf coconut accessions were assessed at the International Coconut Genebank for Latin America and the Caribbean (ICG-LAC). The accessions were planted in 2003 at the Experimental Field of Itaporanga belonging to Embrapa Coastal Tablelands, located in Itaporanga d'Ajuda, SE, on the SE 100, $\mathrm{km} 3\left(11^{\circ} 07^{\prime} \mathrm{S}\right.$ and $37^{\circ}$ $\left.11^{\prime} \mathrm{W}\right), 28 \mathrm{~km}$ from Aracaju.

The accessions Brazilian Green Dwarf-Jiqui (BGDJ), Cameroon Red Dwarf (CRD), Malayan Red Dwarf (MRD), Brazilian Red Dwarf-Gramame (BRDG), Brazilian Yellow Dwarf-Gramame (BYDG), and Malayan Yellow Dwarf (MYD) were assessed during three cultivation cycles from 2014 to 2016, resulting in three assessments indicated as Year 1 (2014), Year 2 (2015), and Year 3 (2016).

The climate of the Itaporanga d'Ajuda region is classified as $\mathrm{A}^{\prime}$ s, i.e., a rainy tropical climate with a dry summer, according to the Köppen classification. The soil of the experimental area is classified as an arenosols (Quartzipsamments) of low natural fertility (MELO-FILHO; SILVA; JACOMINE, 1982). The average temperature of the region is $25.6{ }^{\circ} \mathrm{C}$ and the average monthly precipitation for 2014, 2015, and 2016 were 98, 180, and $99.2 \mathrm{~mm}$, respectively. The cultivation practices and phytosanitary treatments were carried out as normally recommended for the crop (FONTES; FERREIRA, 2016).

The accessions were arranged in a completely randomized block design with five replications with up to 16 useful plants per plot and a spacing of $7.5 \times$ $7.5 \times 7.5 \mathrm{~m}$ in an equilateral triangle. We used 30 quantitative descriptors adapted from the IPGRI (1995) list, being 10 vegetative and 20 of fruits. The vegetative descriptors were the number of live leaves (NLL), number of dead leaves (NDL), number of emitted leaves (NEL), rachis length (RL, m), petiole length (PL, cm), petiole thickness (PT, mm), petiole width (PW, cm), number of leaflets (NL), leaflet length $(\mathrm{LL}, \mathrm{cm})$, and leaflet width $(\mathrm{LW}, \mathrm{cm})$. The fruit descriptors were the soluble solids content of endosperm (water) ( $\left.\mathrm{SSC},{ }^{\circ} \mathrm{Brix}\right), \mathrm{pH}$ of the liquid endosperm $(\mathrm{pH})$, quantity of liquid endosperm (VLE, $\mathrm{mL})$, fruit polar circumference (FPC, $\mathrm{cm}$ ), fruit 
equatorial circumference (FEC, $\mathrm{cm})$, fruit equatorial diameter (FED, cm), fruit polar diameter (FPD, cm), nut polar diameter (NPD, $\mathrm{mm}$ ), nut equatorial diameter (NED, mm), total fruit weight (TFW, kg), fruit weight without liquid endosperm (FWWLE, $\mathrm{kg}$ ), endocarp weight (shell) (EDW, kg), epicarp weight (husk) (EPW, kg), nut weight (NW, kg), solid endosperm weight (solid albumen) (SAW, kg), liquid endosperm weight (LAW, kg), solid endosperm thickness (AWT, mm), endocarp thickness (EDT, $\mathrm{mm}$ ), epicarp thickness (EPT, mm), and number of fruits per plant (NF).

The leaf number 14 in each plant was used for vegetative assessments. Three fruits/plant/accession/ replication had their inflorescences previously marked, being harvested seven months after formation. After harvesting, the fruits were transported, washed, and identified for recording the various fruit descriptors.

\section{Statistical analysis}

The data were analyzed individually (each year) and then a joint analysis was performed using the mean obtained for each descriptor over the three years. The data were tested for ANOVA assumptions, analysis of variance homogeneity (BARTLETT, 1937), and normality (SHAPIRO; WILK, 1965). Descriptors that did not meet the assumptions were transformed and then the ANOVA was performed to observe phenotypic variability among the accessions.

In order to quantify the genetic diversity among the accessions, the Mahalanobis' generalized distance (CRUZ; FERREIRA; PESSONI, 2011) was used. Five individual analyses were carried out with six variables each and the matrices of each analysis corresponding to each year were summed, obtaining a single matrix. For the joint analysis, the matrices of the three years were summed. The hierarchical clustering was obtained from the genetic distance matrix using the UPGMA (unweighted pair group method with arithmetic mean) method (SNEATH; SOKAL, 1973) and the Tocher optimization method. The assessment of the relative importance of traits was measured by the Singh (1981) method and the method of the canonical variables (CRUZ; FERREIRA; PESSONI, 2011). All the analyses were performed using the software GENES (CRUZ, 2016). The clustering consistency was determined by the cophenetic correlation coefficient according to Sokal and Rohlf (1962). The significance of cophenetic correlation coefficients was calculated by the Mantel test with 1000 permutations (MANTEL, 1967). The cut-off point was defined by the Mojena (1977) method and the dendrograms were built using the software R (R DEVELOPMENT CORE TEAM, 2012). For the study of the variance components, considering that the data of accessions were available in one place and with three production cycles, the methodology of mixed linear models (RESENDE, 2002) was used by the restricted maximum likelihood method (REML procedure) and the estimate of the best linear unbiased prediction (BLUP) by the statistical model 9: $\mathrm{y}=\mathrm{Xm}+\mathrm{Zg}+$ $\mathrm{Wp}+\mathrm{Ts}+\mathrm{e}$, where $\mathrm{y}$ is the data vector, $\mathrm{m}$ is the vector of effects of measurement-repeating combinations (assumed to be fixed) added to the overall mean, $\mathrm{g}$ is the vector of genotypic effects (assumed to be random), "p" is the vector of plot effects (random), "s" is the vector of permanent environmental effects (random), and "e" is the vector of errors or residuals (random). Uppercase letters represent the incidence matrices for the respective effects. The parameters were estimated using the genetic-statistical software Selegen-Reml/Blup (RESENDE, 2002). For this analysis, 11 important agronomic descriptors (fruit polar diameter, fruit equatorial diameter, nut polar diameter, nut equatorial diameter, quantity of liquid endosperm, soluble solids content of endosperm, $\mathrm{pH}$ of the liquid endosperm, total fruit weight, epicarp weight, epicarp thickness, and number of fruits) were selected for the dwarf coconut.

\section{RESULTS AND DISCUSSION}

The descriptors related to fruits and leaf distinguished the accessions of dwarf coconut. A total of 23, 26, and 26 descriptors were significant, respectively, in the first, second, and third year, and most of them significant at $1 \%$ level (Table 1). In the joint analysis, considering both the fruit and leaf descriptors, only three descriptors did not present a significant difference (Table 1). Considering the three years and the joint assessment, low coefficients of variation $(\mathrm{CV})$ were observed for the great majority of the descriptors, but with some exceptions, indicating good experimental precision.

The UPGMA cluster method showed the formation of two groups and some subgroups in all years and in the joint analysis (Figure 1). The accession CRD formed an isolated group in years 1 and 2. However, in the joint analysis of year 3, this accession was placed in a subgroup next to other accessions and the first group was formed by the BGDJ and BRDG accessions (Figure 1C). It is important to note that the cophenetic correlation coefficient in this year was 0.70 , i.e. the lowest among the four analyses. The minimum desirable value for this coefficient is 0.80 (ROHLF; FISHER, 1968) and hence the groups formed in this year are less precise and the data may have been influenced by some environmental factors such as precipitation indices, which presented a variation of 98,180 , and $99.2 \mathrm{~mm}$ in years 1,2 , and 3, respectively. However, the coefficients of joint analysis for years 1,2 , and 3 were $0.90,0.82$, and 0.92 , respectively, indicating an accurate separation of the groups.

Rev. Caatinga, Mossoró, v. 32, n. 1, p. 52 - 61, jan. - mar., 2019 
K. M. B. SOBRAL et al.

Table 1. Summary of the variance analysis for the 30 descriptors assessed in six accessions of dwarf coconut preserved at the International Coconut Genebank for Latin America and the Caribbean (ICG-LAC).

\begin{tabular}{|c|c|c|c|c|c|c|c|c|c|c|c|c|}
\hline Descriptors $^{1}$ & \multicolumn{3}{|c|}{ Year1 (2014) } & \multicolumn{3}{|c|}{ Year 2 (2015) } & \multicolumn{3}{|c|}{ Year 3 (2016) } & \multicolumn{3}{|c|}{ Joint analysis } \\
\hline FDP & $0.70^{* *}$ & 4.06 & 21.07 & $0.30 * *$ & 2.84 & 20.19 & $0.09^{* *}$ & 1.53 & 20.22 & $0.10^{* *}$ & 1.99 & 20.50 \\
\hline NPD & $23.80^{*}$ & 4.55 & 107.36 & $25.80^{* *}$ & 4.93 & 103.12 & $5.30^{* *}$ & 2.20 & 104.36 & $10.90^{* *}$ & 3.15 & 104.95 \\
\hline NED & $38.30^{\mathrm{ns}}$ & 6.42 & 95.17 & $36.30^{\mathrm{ns}}$ & 5.95 & 101.26 & $8.10^{* *}$ & 2.65 & 107.34 & $17.50^{\mathrm{ns}}$ & 4.13 & 101.26 \\
\hline FPC & $5.80^{* *}$ & 4.38 & 55.10 & $2.90^{* *}$ & 3.15 & 54.95 & 0.80 ** & 1.66 & 54.56 & $1.70^{* *}$ & 2.40 & 54.87 \\
\hline $\mathrm{SSC}$ & $0.04^{* *}$ & 3.16 & 6.54 & $0.06^{* *}$ & 3.87 & 6.37 & $0.08^{\mathrm{ns}}$ & 4.68 & 6.06 & $0.20^{* *}$ & 7.54 & 6.40 \\
\hline $\mathrm{pH}$ & $0.01^{\mathrm{ns}}$ & 1.62 & 6.31 & $0.01^{* *}$ & 2.24 & 5.26 & $0.00^{* *}$ & 1.48 & 5.21 & $0.00^{* *}$ & 1.06 & 5.60 \\
\hline TFW & $0.05^{* *}$ & 8.95 & $\begin{array}{l}0.61 \\
1.69\end{array}$ & $0.05^{* *}$ & 12.56 & 1.83 & $0.00^{* *}$ & 5.17 & 1.84 & $0.02^{* *}$ & 8.45 & 1.790 \\
\hline FWWLE & $0.03^{* *}$ & 13.23 & 1.46 & $0.02^{* *}$ & 10.75 & 1.50 & $0.00^{* *}$ & 5.89 & 1.43 & $0.01^{* *}$ & 7.82 & 1.450 \\
\hline LAW & $0.00^{\mathrm{ns}}$ & 15.21 & 0.28 & $0.00^{\mathrm{ns}}$ & 21.67 & 0.329 & $0.00^{* *}$ & 6.63 & 0.41 & $0.01^{*}$ & 12.11 & 0.34 \\
\hline SAW & $0.00^{\mathrm{ns}}$ & 16.56 & 0.15 & $0.00^{* *}$ & 15.02 & 0.172 & $0.00^{\mathrm{ns}}$ & 9.34 & 0.17 & $0.00^{* *}$ & 11.27 & 0.17 \\
\hline EDW & $0.00^{*}$ & 10.83 & 0.14 & $0.00^{* *}$ & 15.39 & 0.150 & $0.00^{* *}$ & 6.03 & 0.15 & $0.00^{* *}$ & 9.60 & 0.15 \\
\hline EPT & $2.71^{* *}$ & 7.38 & 22.31 & $0.72^{* *}$ & 4.24 & 20.06 & $1.10^{* *}$ & 6.03 & 17.60 & $0.70^{* *}$ & 4.34 & 19.99 \\
\hline NF & $291.4^{* *}$ & 27.25 & 62.62 & $208.2^{* *}$ & 11.79 & 70.70 & $108.30^{* *}$ & 17.83 & 58.37 & $144.8^{* *}$ & 19.06 & 63.16 \\
\hline NLL & $5.70^{* *}$ & 9.27 & 24.79 & $4.70^{* *}$ & 8.02 & 27.15 & $4.00^{* *}$ & 5.04 & 27.63 & $4.40^{* *}$ & 7.98 & 26.29 \\
\hline NEL & $1.97^{* *}$ & 11.89 & 11.84 & $1.90^{* *}$ & $\begin{array}{l}.02 \\
8.31\end{array}$ & 16.82 & $2.00^{* *}$ & 9.30 & 15.28 & $1.05^{* *}$ & 7.01 & 14.64 \\
\hline NDL & $1.59^{* *}$ & 11.74 & 10.75 & $1.40^{\mathrm{ns}}$ & 18.13 & 6.52 & $2.40^{* *}$ & 12.67 & 12.39 & $0.90^{* *}$ & 9.95 & 9.89 \\
\hline PL & $53.2^{\text {ns }}$ & 6.95 & 104.84 & $55.50^{*}$ & 6.59 & 113.16 & $24.30^{\mathrm{ns}}$ & 4.14 & 119.13 & $32.80^{\mathrm{ns}}$ & 5.10 & 112.38 \\
\hline PW & $0.11^{* *}$ & 4.87 & 6.94 & $0.09^{* *}$ & 4.48 & 6.96 & $0.04^{* *}$ & 3.11 & 6.47 & $0.05^{* * *}$ & 3.38 & 6.80 \\
\hline PT & $0.64^{* *}$ & 3.26 & 24.63 & $1.00^{*}$ & 4.44 & 23.53 & $0.40^{* *}$ & 2.70 & 24.23 & $0.40^{* *}$ & 2.83 & 24.14 \\
\hline RL & $0.07 *$ & 6.89 & 4.09 & $0.04^{*}$ & 4.46 & 4.30 & $0.01^{* *}$ & 2.75 & 4.37 & $2.80^{\mathrm{ns}}$ & 4.47 & 37.97 \\
\hline NL & $20.5^{* *}$ & 2.42 & 187.28 & $113.50^{* *}$ & 1.89 & 184.67 & $9.60^{\mathrm{ns}}$ & 1.67 & 186.57 & $17.80^{* *}$ & 2.28 & 185.19 \\
\hline LL & $59.4^{* *}$ & 6.66 & 115.75 & $146.60^{* *}$ & 5.07 & 117.05 & $18.10^{* *}$ & 3.44 & 123.65 & $43.30^{* *}$ & 5.29 & 119.80 \\
\hline LW & $0.07 * *$ & 5.40 & 5.20 & $0.04^{* *}$ & 4.10 & 5.23 & $0.02^{* *}$ & 3.14 & 4.84 & $0.02^{* *}$ & 2.91 & 5.09 \\
\hline
\end{tabular}

** and ${ }^{*}$ significant to 1 and $5 \%$, respectively, by the teste of $\mathrm{F} ;{ }^{\mathrm{ns}}$ not significant. Descriptors: FPD = fruit polar diameter $(\mathrm{cm}), \mathrm{FED}=$ fruit equatorial diameter $(\mathrm{cm}), \mathrm{NPD}=$ nut polar diameter $(\mathrm{mm}), \mathrm{NED}=$ nut equatorial diameter $(\mathrm{mm})$, $\mathrm{FPC}=$ fruit polar circumference $(\mathrm{cm}), \mathrm{FEC}=$ fruit equatorial circumference $(\mathrm{cm}), \mathrm{VLE}=$ quantity of liquid endosperm $(\mathrm{mL}), \mathrm{SSC}=$ soluble solids content of endosperm (water) $\left({ }^{\circ} \mathrm{Brix}\right), \mathrm{pH}=$ of the liquid endosperm $(\mathrm{pH}), \mathrm{TFW}=$ total fruit weight $(\mathrm{kg}), \mathrm{FWWLE}=$ fruit weight without liquid endosperm $(\mathrm{kg}), \mathrm{LAW}=$ liquid endosperm weight $(\mathrm{kg}), \mathrm{SAW}=$ solid endosperm weight (solid albumen) $(\mathrm{kg}), \mathrm{EDW}=$ endocarp weight (shell) $(\mathrm{kg}), \mathrm{NW}=$ nut weight $(\mathrm{kg}), \mathrm{EPW}=$ epicarp weight (husk) $(\mathrm{kg})$, AWT $=$ solid endosperm thickness $(\mathrm{mm})$, EDT $=$ endocarp thickness $(\mathrm{mm})$, EPT $=$ epicarp thickness (mm), NF = number of fruits per plant (unit), NLL = number of live leaves (unit), NEL = number of emitted leaves (unit), $\mathrm{NDL}=$ number of dead leaves (unit), $\mathrm{PL}=$ petiole length $(\mathrm{cm}), \mathrm{PW}=$ petiole width $(\mathrm{cm}), \mathrm{PT}=$ petiole thickness $(\mathrm{mm}), \mathrm{RL}=$ rachis length $(\mathrm{m}), \mathrm{NL}=$ number of leaflets (unit), $\mathrm{LL}=$ leaflet length $(\mathrm{cm})$, and $\mathrm{LW}=$ leaflet width $(\mathrm{cm}) . \mathrm{CV}=$ coefficient of variation, $\mathrm{MS}=$ mean squares.

Thus, the results indicate that the accession CRD was different from the others (Figures 1A, 1B, $1 \mathrm{C}$, and 1D). The other accessions maintained a constant position in the second group but forming different subgroups. In particular, the MRD and BRDG accessions were very close in the same subgroup in years 1,2 , and 3 and in the joint analysis, as well as the BYDG and MYD accessions, which were also shown to be very close when considering all years and the joint assessment. The accession BGDJ was isolated in a division within the subgroup (Figures 1A, 1B, 1C, and 1D). These results indicate a diversity between the accessions, especially for CRD in relation to the others, and show a great similarity between the pairs of accessions BYDG and MYD in one subgroup and MRD and BRDG in another subgroup.

The molecular data of a study performed with all dwarf coconut accessions showed the accessions in a single cluster, with BGDJ and MYD as the most distant (DAHER et al., 2002). It is important to note that these data were not consistent with the present study since the formation of at least two groups was observed in the joint analysis (Figures 1A, 1B, 1C, and 1D). This difference found among the results is probably because molecular markers, especially those used by the authors (RAPD), use tags that anneal to random regions of the genome of plants and are not associated with the numerous assessed traits. 


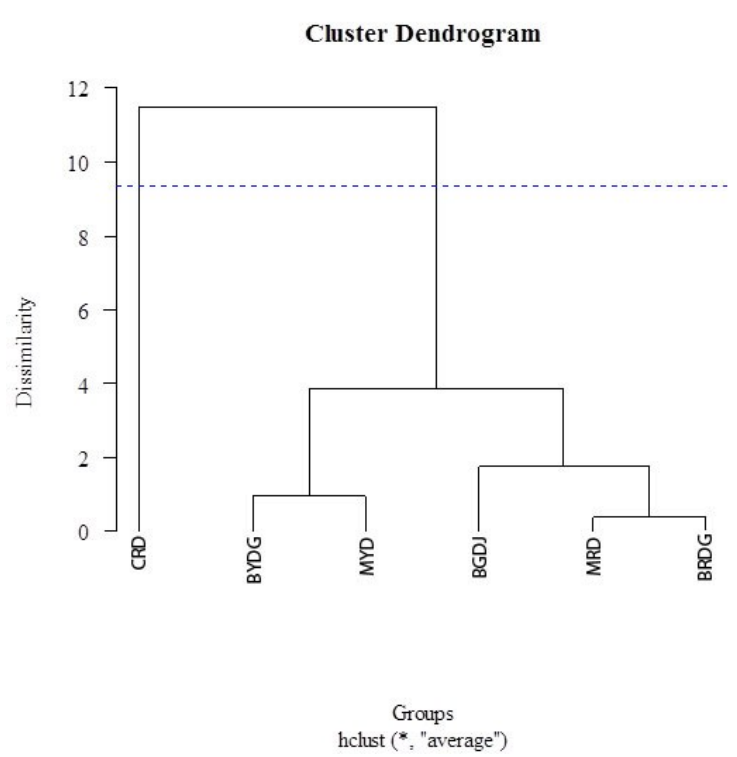

A

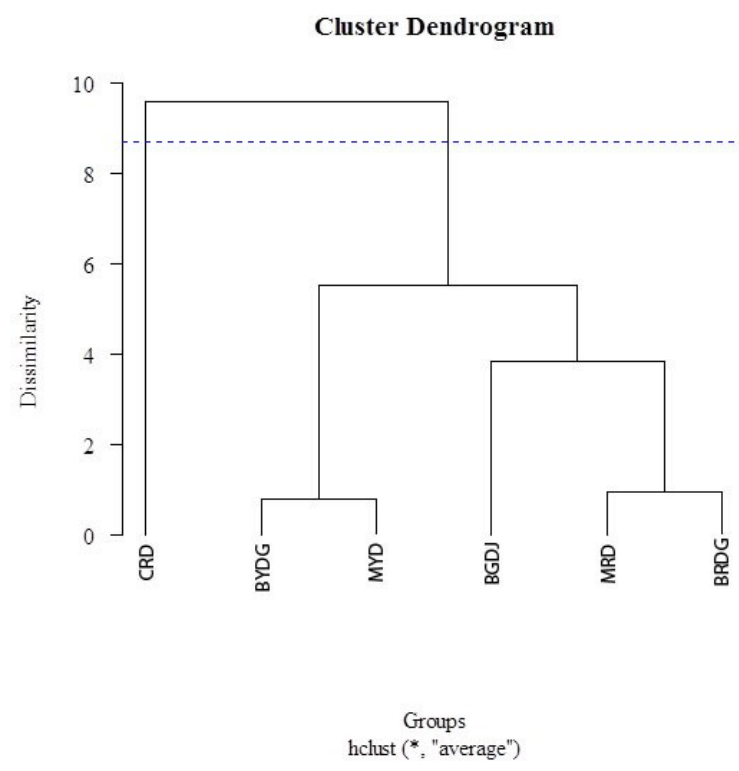

C

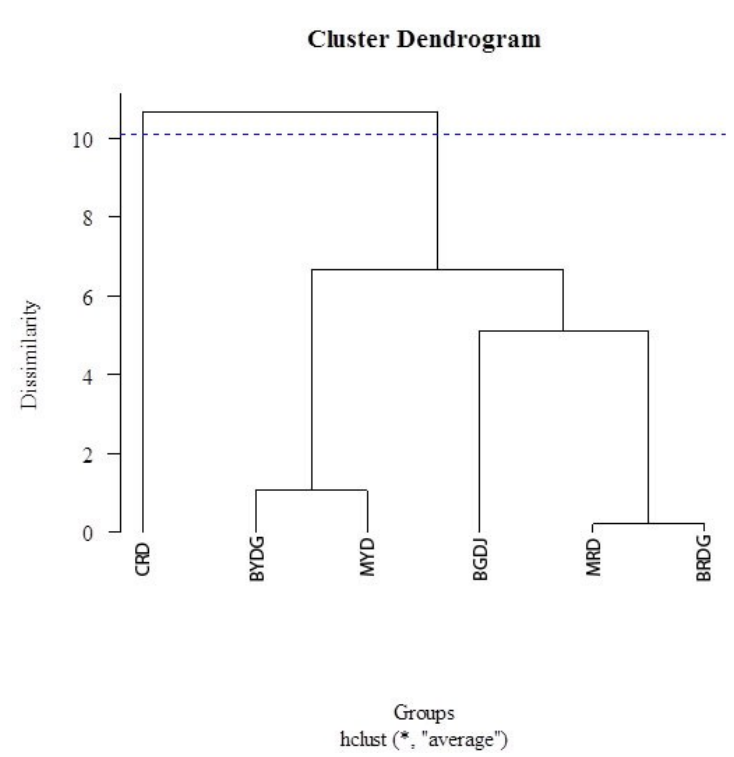

B

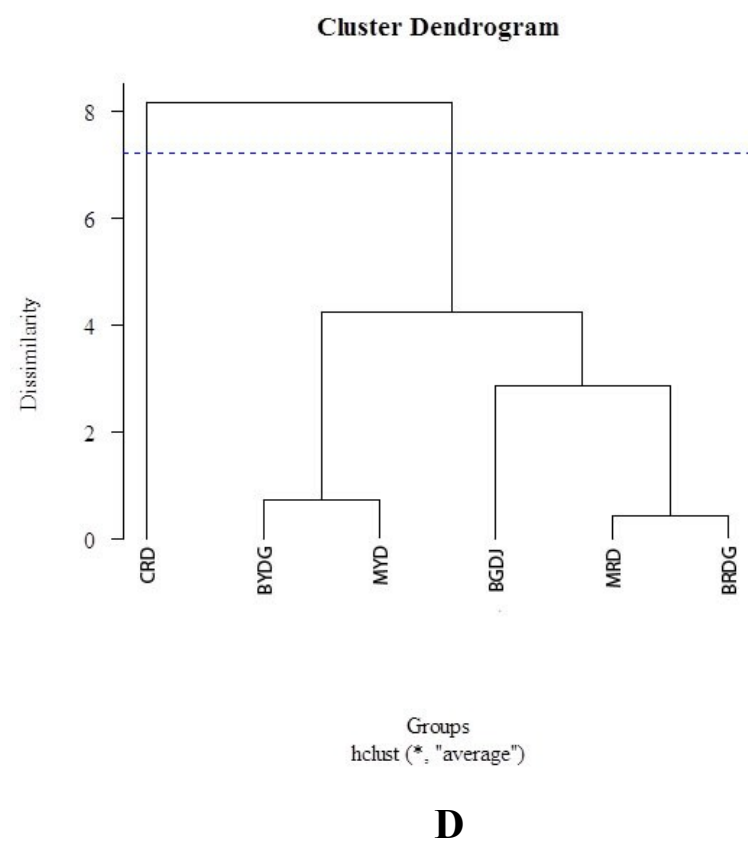

Figure 1. Dendrogram based on the Mahalanobis distance and UPGMA cluster method for six dwarf coconut accessions estimated from 30 quantitative descriptors referring to years 1 (A), 2 (B), and 3 (C) and the joint analysis of these years (D).

A difference was also observed between the data found in this study when compared to those found by Sobral et al. (2012). These authors assessed, in a single cycle, dwarf coconut accessions by means of vegetative and reproductive descriptors. The differences between the accessions in both studies are credited to the difference in the ages of the assessed plants ( 6 and 11 years, respectively), the number of descriptors used (49 and 30, respectively), as well as the number of assessed production cycles
(1 and 3, respectively). In addition, the quantitative phenotypic descriptors are usually of low heritability and the recommendation is for them to be assessed for more production cycles, which was considered in this study, as recommended by Santos et al. (1996). According to these authors, five years is considered a good period for the assessment of vegetative data, four years for fruit components, and at least 10 production cycles for flowering and yield and production stability data. 
K. M. B. SOBRAL et al.

Table 2. Clustering by the Tocher method in six dwarf coconut accessions based on the dissimilarity expressed by the Mahalanobis' generalized distance estimated from 30 quantitative descriptors in years 1, 2, and 3 and in the joint analysis.

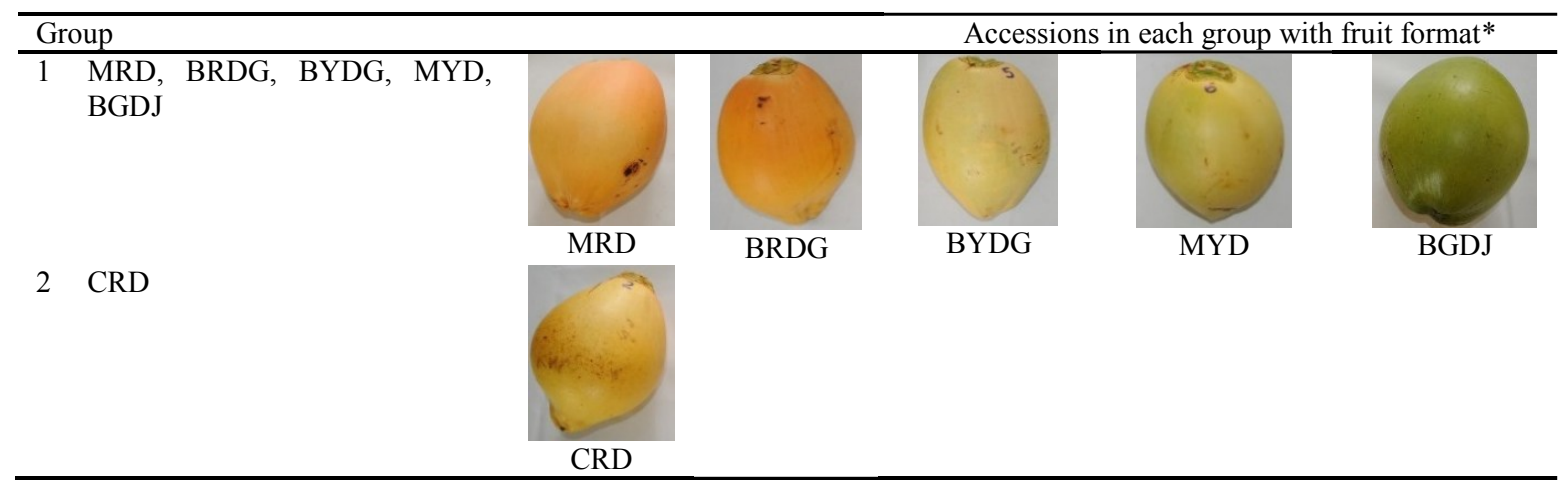

*Accessions: MRD - Malayan Red Dwarf; BRDG - Brazilian Red Dwarf-Gramame; BYDG - Brazilian Yellow DwarfGramame; MYD - Malayan Yellow Dwarf; BGDJ - Brazilian Green Dwarf-Jiqui; CRD - Cameroon Red Dwarf.

The Tocher optimization clustering method revealed the formation of two groups for years 1,2 , and 3 and joint analysis (Table 2). The results are consistent with those observed in the UPGMA cluster analysis. When considering the individual (years 1,2, and 3) and joint analyses, the clustering formed by the Tocher optimization method showed the same pattern in the grouping formation, with accessions BGDJ, MRD, BRDG, BYDG and MYD in one group and the accession CRD in another group.

In general, when observing the clustering formed by UPGMA and Tocher optimization analyses, the accession CRD is the most dissimilar among those assessed since it is not grouped to any other accession. This accession presents interesting characteristics that can facilitate the harvest such as leaf arrangement and low plant height. The fruits have physical attributes similar to BGDJ, which is the most used in commercial production (MACIEL et al., 2009). However, traits such as lower endocarp thickness make the fruit more susceptible to a higher nut breakage, causing losses during transportation (RIBEIRO et al., 1999).

The analyses showed a consistent genetic divergence between dwarf coconut accessions from ICG-LAC since the same groupings were formed in years 1,2, and 3 and in the joint analysis of the data. However, different results were obtained by Cambuí, Aragão and Leal, (2007), which were probably because both studies were carried out in different environments and periods, with plants of different ages, sample size (number of plants considered in the analysis), number and state of descriptors (according to the period, work objective, and plant age), and choice of estimated genetic distance for the analysis of the obtained results.

The use of the Singh (1981) method showed that about 10 to 11 descriptors in years 1,2 , and 3 and in the joint analysis presented an importance level above $3 \%$ and, in a few cases, reaching up to $21.66 \%$ for the descriptor FPC in the joint analysis
(Table 3). Most of the descriptors (50\%) presented a contribution below 1\% (Table 3). Thirty-three percent of the descriptors showed a good contribution ranging from 10.47 to $21.60 \%$ in the different years. Only the descriptor FPC was present in at least three analyses (Table 3). These data did not indicate a greater consistency in the discrimination capacity of the descriptor over the years, showing the need to continue the accession assessments, as established for the crop (SANTOS et al., 1996). In this case, more assessment cycles would be required for some descriptors, which would possibly allow a greater stability and consistency of the data of the assessed plants. It is important to deepen these observations by analyzing different aspects of the descriptors, such as the correlation between them, in order to have a selection of descriptors that may be more appropriate for the understanding of dwarf coconut accessions.

To confirm the variability shown in the previous analyses, the data were plotted in scatter plots. The first two canonical variables explained more than $80 \%$ of the variation in each year and in the joint assessment (Figure 2). In fact, it is desirable that the percentage of accumulated variation in the first two canonical variables be higher than $80 \%$ (CRUZ; FERREIRA; PESSONI, 2011).

The scatter plots for the three assessed years and joint analysis were in accordance with the results for UPGMA clusters and Tocher optimization, which are similar to the results obtained from the genetic diversity between accessions and their respective groups and subgroups (Figure 1 and Table 2).

The results presented and discussed to date consistently indicate that the dwarf coconut accessions present a genetic divergence as attested by the univariate and multivariate analyses. However, since it is an autogamous crop (PASSOS, 1998), it is very important to examine the components of variance in order to have reliable information about the existence of the genetic variance for the descriptors, especially those most 
important for breeding programs.

The analyses using the maximum likelihood (RESENDE, 2002) show that, in fact, there is a genetic variance for some descriptors and these variances in relation to the environmental variances (Table 4) allow heritability even in a broad sense, which indicates the possibility of genetic gains in breeding. Thus, the individual broad sense heritability $\left(\mathrm{h}^{2} \mathrm{G}\right)$ estimated for the descriptors fruit polar and equatorial diameter and nut polar diameter presented values from 0.17 to 0.21 , while the total fruit weight and epicarp thickness presented heritability values of 0.39 and 0.33 , respectively, indicating the possibility of genetic gains through selection. Thus, considering the current demand scenario, the germplasm bank of dwarf coconut preserves and provides satisfactory genetic variability to be worked on breeding programs that consider both advances in intravarietal (dwarf X dwarf) and intervarietal (tall $\mathrm{X}$ dwarf) crosses conducted in Brazil.

Table 3. Relative importance of the 30 descriptors for the assessment of the genetic diversity in dwarf coconut accessions in years 1, 2, and 3 and in the joint analysis between the years using the Singh (1981) method.

\begin{tabular}{|c|c|c|c|c|c|c|c|c|}
\hline & \multicolumn{2}{|c|}{ Year I } & \multicolumn{2}{|c|}{ Year II } & \multicolumn{2}{|c|}{ Year III } & \multicolumn{2}{|c|}{ Joint analysis } \\
\hline Descriptors $^{1}$ & $\%$ & TAV & $\%$ & TAV & $\%$ & TAV & $\%$ & TAV \\
\hline FDP & 9.09 & 9.09 & 0.72 & 0.72 & 3.45 & 3.45 & 16.63 & 16.63 \\
\hline FED & 11.86 & 20.95 & 4.52 & 5.24 & 1.03 & 4.47 & 1.46 & 18.09 \\
\hline NPD & 2.06 & 23.01 & 8.72 & 13.96 & 2.16 & 6.64 & 11.60 & 29.69 \\
\hline NED & 0.98 & 23.99 & 7.81 & 21.76 & 1.76 & 8.39 & 3.51 & 33.21 \\
\hline FPC & 10.47 & 34.47 & 0.94 & 22.70 & 7.74 & 16.13 & 21.66 & 54.87 \\
\hline FEC & 2.57 & 37.03 & 4.61 & 27.31 & 12.28 & 28.41 & 1.19 & 56.06 \\
\hline VLE & 1.48 & 38.51 & 1.16 & 28.46 & 4.67 & 33.08 & 4.78 & 60.84 \\
\hline SSC & 0.05 & 38.57 & 1.19 & 29.65 & 0.43 & 33.51 & 0.38 & 61.22 \\
\hline $\mathrm{pH}$ & 0.16 & 38.73 & 0.21 & 29.87 & 0.74 & 34.25 & 0.91 & 62.13 \\
\hline TFW & 0.47 & 39.20 & 0.78 & 30.65 & 1.37 & 35.62 & 1.90 & 64.03 \\
\hline FWWLE & 0.08 & 39.28 & 0.35 & 30.99 & 0.32 & 35.94 & 0.49 & 64.52 \\
\hline LAW & 0.06 & 39.34 & 0.02 & 31.02 & 0.29 & 36.22 & 0.35 & 64.87 \\
\hline SAW & 0.01 & 39.35 & 0.08 & 31.10 & 0.05 & 36.27 & 0.46 & 65.33 \\
\hline EDW & 0.01 & 39.36 & 0.03 & 31.12 & 0.04 & 36.31 & 0.40 & 65.73 \\
\hline NW & 0.01 & 39.38 & 0.23 & 31.36 & 0.93 & 37.24 & 1.16 & 66.89 \\
\hline EPW & 4.90 & 44.28 & 0.93 & 32.29 & 2.16 & 39.40 & 0.48 & 67.37 \\
\hline AWT & 0.87 & 45.15 & 7.82 & 40.11 & 2.07 & 41.47 & 0.74 & 68.11 \\
\hline EDT & 1.60 & 46.75 & 0.24 & 40.35 & 0.20 & 41.67 & 1.64 & 69.74 \\
\hline EPT & 6.91 & 53.66 & 18.22 & 58.56 & 4.70 & 46.37 & 2.22 & 71.96 \\
\hline NF & 0.68 & 54.34 & 8.81 & 67.38 & 4.40 & 50.77 & 9.15 & 81.11 \\
\hline NLL & 7.70 & 62.04 & 4.23 & 71.61 & 14.68 & 65.44 & 0.64 & 81.76 \\
\hline NEL & 0.96 & 62.99 & 0.75 & 72.35 & 7.31 & 72.75 & 6.55 & 88.31 \\
\hline NDL & 0.72 & 63.71 & 0.51 & 72.86 & 4.79 & 77.54 & 2.40 & 90.71 \\
\hline PL & 0.26 & 63.98 & 1.62 & 74.48 & 2.11 & 79.65 & 2.14 & 92.85 \\
\hline PW & 1.62 & 65.60 & 0.97 & 75.46 & 1.81 & 81.46 & 1.61 & 94.46 \\
\hline PT & 13.41 & 79.01 & 0.59 & 76.04 & 8.81 & 90.27 & 0.90 & 95.36 \\
\hline $\mathrm{RL}$ & 0.68 & 79.70 & 1.70 & 77.74 & 2.07 & 92.34 & 0.01 & 95.37 \\
\hline NL & 4.59 & 84.29 & 11.58 & 89.32 & 0.90 & 93.24 & 2.09 & 97.46 \\
\hline LL & 12.59 & 96.88 & 9.57 & 98.89 & 4.43 & 97.67 & 1.67 & 99.13 \\
\hline LW & 3.12 & 100.00 & 1.11 & 100.00 & 2.33 & 100.00 & 0.87 & 100.00 \\
\hline
\end{tabular}

${ }^{1}$ Descriptors: FPD $=$ fruit polar diameter $(\mathrm{cm})$, FED $=$ fruit equatorial diameter $(\mathrm{cm}), \mathrm{NPD}=$ nut polar diameter $(\mathrm{mm}), \mathrm{NED}=$ nut equatorial diameter $(\mathrm{mm}), \mathrm{FPC}=$ fruit polar circumference $(\mathrm{cm})$, $\mathrm{FEC}=$ fruit equatorial circumference $(\mathrm{cm}), \mathrm{VLE}=$ quantity of liquid endosperm $(\mathrm{mL}), \mathrm{SSC}=$ soluble solids content of endosperm (water) $\left({ }^{\circ} \mathrm{Brix}\right), \mathrm{pH}=$ of the liquid endosperm ( $\left.\mathrm{pH}\right), \mathrm{TFW}=$ total fruit weight $(\mathrm{kg}), \mathrm{FWWLE}=$ fruit weight without liquid endosperm $(\mathrm{kg}), \mathrm{LAW}=$ liquid endosperm weight $(\mathrm{kg}), \mathrm{SAW}=$ solid endosperm weight (solid albumen) $(\mathrm{kg}), \mathrm{EDW}=$ endocarp weight (shell) $(\mathrm{kg}), \mathrm{NW}=$ nut weight $(\mathrm{kg}), \mathrm{EPW}=$ epicarp weight (husk) $(\mathrm{kg}), \mathrm{AWT}=$ solid endosperm thickness $(\mathrm{mm})$, EDT $=$ endocarp thickness $(\mathrm{mm})$, EPT $=$ epicarp thickness $(\mathrm{mm}), \mathrm{NF}=$ number of fruits per plant (unit), NLL = number of live leaves (unit), NEL $=$ number of emitted leaves (unit), $\mathrm{NDL}=$ number of dead leaves (unit), $\mathrm{PL}=$ petiole length $(\mathrm{cm}), \mathrm{PW}=$ petiole width $(\mathrm{cm}), \mathrm{PT}=$ petiole thickness $(\mathrm{mm}), \mathrm{RL}=$ rachis length $(\mathrm{m}), \mathrm{NL}=$ number of leaflets (unit), $\mathrm{LL}=$ leaflet length $(\mathrm{cm})$, and $\mathrm{LW}=$ leaflet width $(\mathrm{cm})$. TAV $=$ Total Accumulated Variance. 


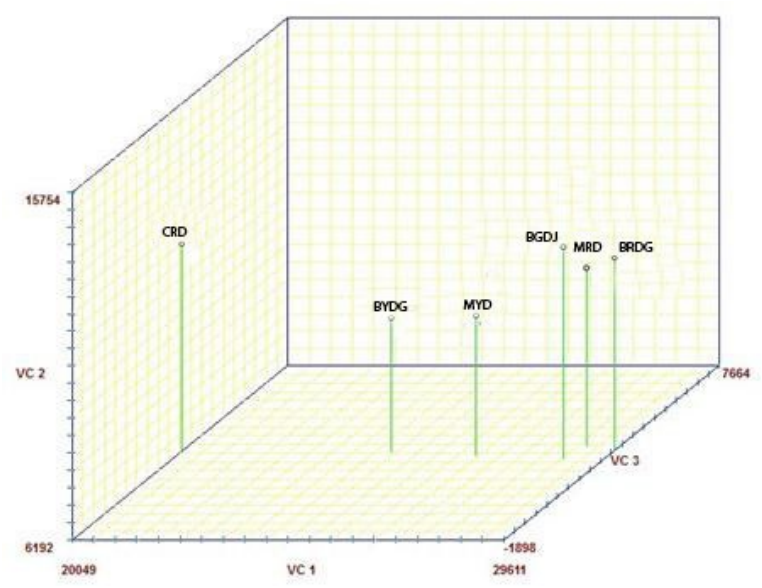

A

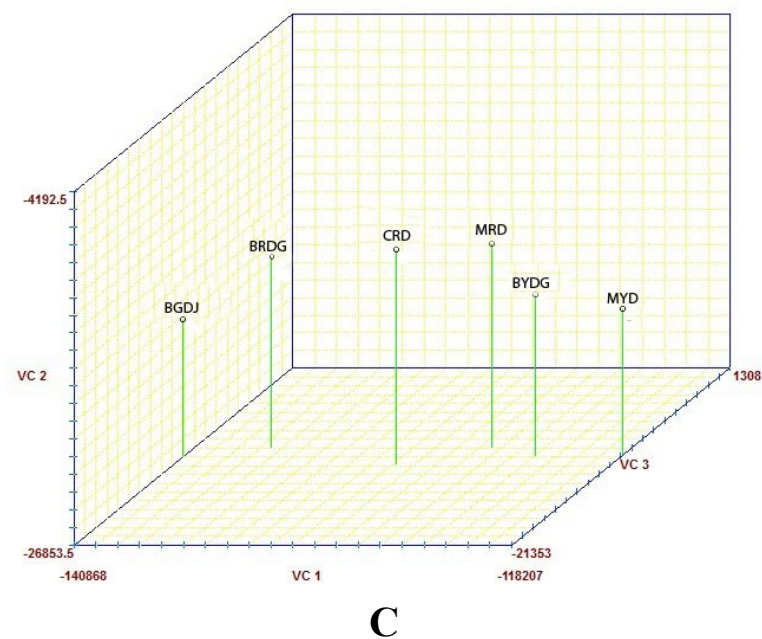

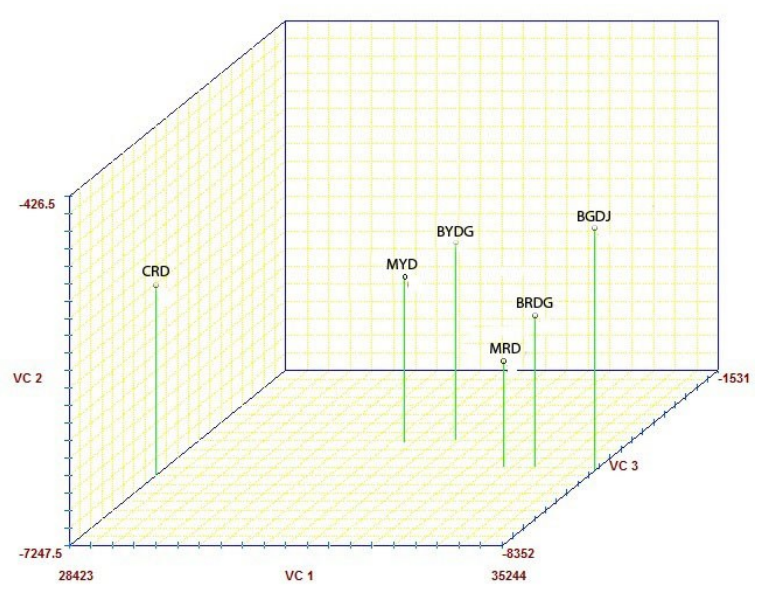

B

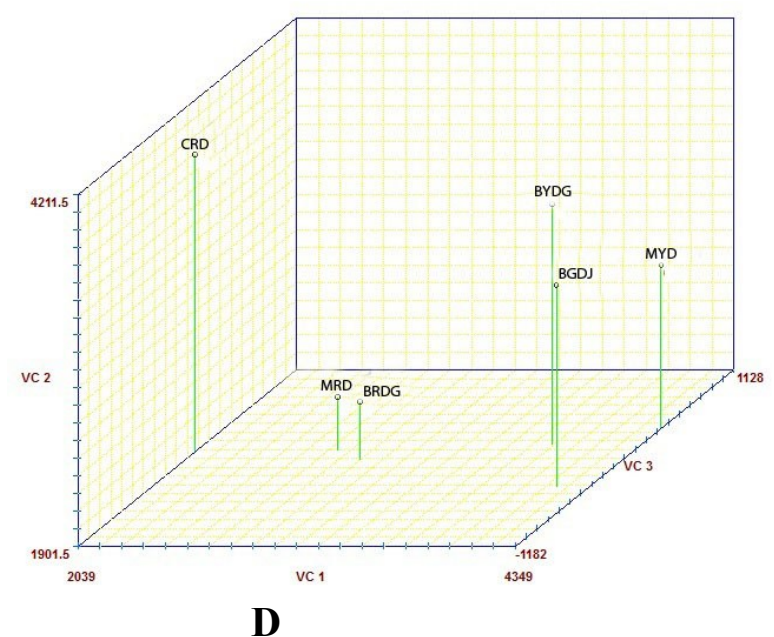

Figure 2. Dispersion of scores of six dwarf coconut accessions in relation to the first two canonical variables (CV1 and CV2) and accumulated variance (\%) based on agronomic traits measured in years 1 (A), 2 (B), and 3 (C) and in the joint analysis for these years (D).

According to Guerra et al. (2009), the coefficients of determination of plot effects (c2plot) quantify the variability within blocks. The nut equatorial diameter, quantity of the liquid endosperm, $\mathrm{pH}$, and the number of fruits had a very low genetic variance $(0.01$ to 0.07$)$, higher plot effects (Table 4), and low heritability. The other descriptors presented a low magnitude ( 0.05 to 0.24 ), indicating a low environmental variation between plots within the block, in addition to indicating that the experimental design was adequate since the environmental homogeneity within blocks remained for these traits.

The results of the maximum likelihood analyses are important because they corroborate the results obtained with the univariate and multivariate analyses and indicate the existence of genetic variability in the germplasm of dwarf coconut preserved in the ICG-LAC. From them, we will be able to select superior individuals for different coconut production environments based on the main descriptors which are of economic importance. 
Table 4. Estimates of genotypic variance (Vg), environmental variance between plots (Vplot), residual variance (Ve), individual phenotypic variance (Vf), individual broad sense heritability $\left(h^{2} \mathrm{G}\right)$, and coefficient of determination of plot effects (c2plot) using 11 descriptors of economic importance in the International Coconut Genebank for Latin America and the Caribbean (ICG-LAC).

\begin{tabular}{lcccccc}
\hline Descriptors $^{1}$ & $\mathrm{Vg}$ & $\mathrm{Vparc}$ & $\mathrm{Ve}$ & $\mathrm{Vf}$ & $\mathrm{h}^{2} \mathrm{G}$ & $\mathrm{c} 2 \mathrm{parc}$ \\
\hline FDP & 0.62 & 0.77 & 2.19 & 3.60 & $0.17 \pm 0.04$ & 0.21 \\
FED & 0.58 & 0.52 & 1.62 & 2.74 & $0.21 \pm 0.05$ & 0.19 \\
NPD & 13.08 & 19.18 & 44.13 & 76.82 & $0.17 \pm 0.04$ & 0.24 \\
NED & 2.18 & 47.56 & 69.80 & 120.00 & $0.01 \pm 0.01$ & 0.39 \\
VLE & 602.26 & 4554.18 & 5476.74 & 10676.53 & $0.05 \pm 0.02$ & 0.42 \\
SSC & 0.02 & 0.02 & 0.37 & 0.42 & $0.05 \pm 0.02$ & 0.05 \\
pH & 0.00 & 0.28 & 0.05 & 0.34 & $0.00 \pm 0.00$ & 0.84 \\
TFW & 0.08 & 0.03 & 0.08 & 0.20 & $0.39 \pm 0.07$ & 0.17 \\
EPW & 0.07 & 0.01 & 0.04 & 0.13 & $0.57 \pm 0.08$ & 0.11 \\
EPT & 8.15 & 6.00 & 10.04 & 24.31 & $0.33 \pm 0.06$ & 0.24 \\
NF & 108.48 & 392.89 & 867.36 & 1378.79 & $0.07 \pm 0.03$ & 0.28 \\
\hline
\end{tabular}

${ }^{1}$ Descriptors: $\mathrm{FPD}=$ fruit polar diameter $(\mathrm{cm}), \mathrm{FED}=$ fruit equatorial diameter $(\mathrm{cm}), \mathrm{NPD}=$ nut polar diameter $(\mathrm{mm})$, $\mathrm{NED}=$ nut equatorial diameter $(\mathrm{mm}), \mathrm{VLE}=$ quantity of liquid endosperm $(\mathrm{mL}), \mathrm{SSC}=$ soluble solids content of endosperm (water) $\left({ }^{\circ} \mathrm{Brix}\right), \mathrm{pH}=$ of the liquid endosperm $(\mathrm{pH}), \mathrm{TFW}=$ total fruit weight $(\mathrm{kg}), \mathrm{EPW}=$ epicarp weight (husk) $(\mathrm{kg}), \mathrm{EPT}=$ epicarp thickness $(\mathrm{mm}), \mathrm{NF}=$ number of fruits per plant (unit).

\section{CONCLUSIONS}

There is a genetic variability for fruit traits in dwarf coconut accessions preserved in Brazil.

The coconut variety Cameroon Red Dwarf is the most divergent accession among those considered in this study.

The descriptors used in this study are efficient in estimating the genetic variability among accessions.

The descriptors fruit polar and equatorial diameter, fruit nut polar diameter, total fruit weight, and epicarp thickness are liable to genetic gain through selection.

\section{ACKNOWLEDGMENTS}

The authors thank Mariana N. R. Lima for the statistical support. To the MAPA/SNPC for the financial support and to the Embrapa Coastal Tablelands for the facilities to carry out work in the field and in the laboratory.

\section{REFERENCES}

ARAGÃO, W. M. et al. Florescimento, produção e composição morfológica de frutos de cultivares de coqueiro. Agrotrópica, v. 14, n. 3, p. 151-158, 2002.

BARTLETT, M. S. Properties of sufficiency and statistical tests. Proceedings of the Royal Society, v. 160, s/n., p. 268-282, 1937.

CAMBUÍ, E. V. F.; ARAGÃO, W. M; LEAL, M. L. S. Variabilidade genética entre cultivares de coqueiro anão (Cocos nucifera, L. var. nana). Revista Brasileira de Biociências, v. 5, Sup., p. 165-167, 2007.

CRUZ, C. D.; FERREIRA, F. M; PESSONI, L. A. Biometria Aplicada ao Estudo da Diversidade Genética. 1 ed. Viçosa, MG: UFV, 2011. 620 p.

CRUZ, C. D. Genes Software - extended and integrated with the R, Matlab and Selegen. Acta Scientiarum, v. 38, n. 4, p. 547-552, 2016.

DAHER, R. F. et al. Assessment of coconut tree genetic divergence by compound sample RAPD marker analysis. Crop Breeding and Applied Biotechnology, v. 2, n. 3, p. 431-438, 2002.

FOOD AND AGRICULTURE ORGANIZATION OF THE UNITED NATIONS - FAOSTAT. Culturas ano 2016. Disponível em: $<\mathrm{http}: / /$ www.fao.org/faostat/en/\#data/QC $>$ Acesso em:19 abr. 2018 .

FONTES, H. R.; FERREIRA, J. M. S. A cultura do coqueiro. 2.ed. Aracaju: Embrapa Tabuleiros Costeiros; Brasília: Embrapa Informação Tecnológica, 2016. (Sistemas de Produção, 1).

GUERRA, C. R. S. B. et al. Estratégias de seleção dentro de progênies em duas populações de Myracrodruon urundeuva Fr. All. Scientia Forestalis, v. 37, n. 81, p. 79-87, 2009.

INTERNATIONAL PLANT GENETIC RESOURCES INSTITUTE - IPGRI. Descriptors for Coconut (Cocos nucifera L.). International Plant Genetic Resources Institute, Rome, Italy, 68 p. 1995. 
LIYANAGE, D. V. Varieties and forms of the coconut palm grown in Ceylon. Ceylon Coconut Quarterly, v. 9, s/n, p. 1-10, 1958.

MACIEL, V. T. et al. Caracterização física dos frutos de seis cultivares de coqueiro-anão em diferentes estádios de desenvolvimento. Revista Brasileira de Ciências Agrárias, v. 4, n. 4, p. 395 398, 2009.

MANTEL, N. The detection of disease clustering and generalized regression approach. Cancer Research, v. 27, n. 2, p. 209-220, 1967.

MARTINS, C. R.; JESUS JUNIOR, L. A. Produção e comercialização de coco no Brasil frente ao comércio internacional: panorama 2014. 1. ed. Aracaju: Embrapa Tabuleiros Costeiros, 51 p. 2014 (Documentos, 184).

MELO FILHO, H. F. R.; SILVA, F. B. R.; JACOMINE, P. K. T. Levantamento detalhado dos solos da Fazenda, UEPAE/ARACAJU. Rio de Janeiro: Empresa Brasileira de Pesquisa Agropecuária; Serviço Nacional de Levantamento e Conservação de Solos, 1982, 59 p. (Boletim Técnico,78).

MOJENA, R. Hierarquical grouping method and stopping rules: an evaluation. Computer Journal, v. 20, n. 4, p. 359-363, 1977.

OHLER, J. G. Coconut, tree of life. Rome: FAO, 1984. $446 \mathrm{p}$.

PASSOS, E. E. M. Morfologia do coqueiro. In: FERREIRA, J. M. S; WARWICK, D. R; SIQUEIRA, L. A. (Eds.) A cultura do coqueiro no Brasil. Brasília: Embrapa-SPI; 1998, v. 2, cap. 2, p. 57-64.

R DEVELOPMENT CORE TEAM. R. A Language and Environment for Statistical Computing. R Foundation for Statistical Computing, Vienna, Áustria. 2012.

RESENDE, M. D. V. Software Selegen-REML/ BLUP. Curitiba: Embrapa Florestas, 2002. 66 p. (Documentos, 77).

RESENDE, M. D. V. Genética biométrica e estatística no melhoramento de plantas perenes. 1 . ed. Brasília, DF: Embrapa Informação Tecnológica, Brasília, 2002, 975 p.

RIBEIRO, F. E. et al. O coqueiro-anão no Brasil. Aracaju: Embrapa Tabuleiros Costeiros, 1999. 22 p. (Documentos, 8).
ROHLF, F. S.; FISHER, D. L. Test for hierarchical structure in random sets. Systematic Zoology, v. 17, n. 4, p. 407-412. 1968.

SANTOS, G. A. et al. Manual on standardized research techniques in coconut breeding. International Plant Genetic Resources Institute, Rome, Italy, 1996. 46 p.

SHAPIRO, S. S.; WILK, M. B. An analysis of variance teste for normality. Biometrika, v. 52, n. 34, p. 591-611, 1965.

SINGH, D. The relative importance of characters affecting genetic divergence. The Indian Journal of Genetic and Plant Breeding, v. 41, n. 2, p. 237-245, 1981.

SNEATH, P. H.; SOKAL, R. R. Numerical taxonomy: The principles and practice of numerical classification. San Francisco: W. H. Freeman, 1973. $573 \mathrm{p}$.

SOBRAL, K.M.B. Variabilidade genética entre acessos de coqueiro-anão utilizando técnicas de análise multivariada. Magistra, v. 24, n. 4, p. 348 $359,2012$.

SOKAL, R. R.; ROHLF, F. J. The comparison of dendrograms by objective methods. Taxon, v. 11, n. 2, p. 33-40, 1962. 